\title{
PENGARUH STRUKTUR MODAL, NET PROFIT MARGIN (NPM) DAN UKURAN PERUSAHAAN TERHADAP KEBIJAKAN DIVIDEN PADA PERUSAHAAN SUB SEKTOR CONSUMERGOODSYANG TERDAFTAR DI BURSA EFEKINDONESIA PERIODE 2011-2015
}

\author{
Mahmuddin Syah Lubis ${ }^{1}$, Yusneni Afrita Nasution ${ }^{2}$, Elim Suryenti ${ }^{3}$ \\ Fakultas Ekonomi, Universitas Prima Indonesia \\ mahmuddinsyah@gmail.com ${ }^{1}$, yusneniafrita@gmail.com² ${ }^{2}$ elimsurienti@gmail.com³
}

\begin{abstract}
The objective of the research was to examine and analyze the influence of capital structure, net profit margin and company size on dividend policy in consumer goods sub-sector companies listed in the Indonesia Stock Exchange period 2011-2015. The research used descriptive research methode. The population was 40 companies in the consumer goods sub-sector listed in the Indonesia Stock Exchange for the period 2011 - 2015, and 17 of them were used as the samples, taken by using purposive sampling technique. The data were analyzed by using multiple linear regression using SPSS. The results of the research showed that the variables of Capital Structure, Net Profit Margin and Company Size simultaneously had influence on Dividend Policy. Partially, Capital Structure had insignificant influence on Dividend Policy, Net Profit Margin had positive and significant influence on Dividend Policy and Company Size had positive and significant influence on Dividend Policy.
\end{abstract}

Keywords: Capital Structure, Net Profit Margin, Company Size and Dividend Policy

\section{PENDAHULUAN}

Seiring berkembangnya era globalisasi saat ini, pasar modal di Indonesia juga semakin pesat. Hal ini dapat dibuktikan dengan jumlah perusahaan pada tahun 2011 yang go public sebanyak 442 perusahaan dan meningkat menjadi 525 perusahaan pada tahun 2015. Perusahaan dapat dikatakan go public apabila sudah mendaftarkan diri di Bursa Efek Indonesia guna menarik minat banyak investor untuk membeli sahamnya. Sehingga salah satu tujuan dari suatu perusahaan dalam usaha mendapatkan laba sebanyakbanyaknya adalah agar dapat membayar dividen yang diharapkan pemegang saham.

Sektor industri barang konsumsi (Consumer Goods) merupakan sektor yang menjual produk rumah tangga yang dibutuhkan secara rutin dan terus menerus oleh masyarakat. Indonesia sebagai negara dengan populasi penduduk terbanyak di Asia Tenggara menjadikannya negara dengan tingkat konsumsi terbesar di Asia Tenggara. Sampai tahun 2015 sudah ada 40 perusahan sub sektor consumer goods yang terdaftar di Bursa Efek Indonesia dan angka tersebut masih dapat meningkat seiring meningkatnya kebutuhan konsumsi masyarakat setiap harinya. Perkembangan yang baik pada industri consumer goods tersebut membuat industri ini lebih menjanjikan dan diminati para investor. Perusahaan mempunyai 
kewajiban membayar dividen setelah memperoleh laba. Dari seluruh laba yang diperoleh, perusahaan akan membagikan sebagian labanya kepada pemegang saham berupa dividen. Penentuan jumlah besarnya dividen yang akan dibagikan tersebut merupakan Kebijakan Dividen dari pimpinan perusahaan berdasarkan keputusan rapat umum pemegang saham (RUPS). Struktur modal merupakan masalah yang penting bagi perusahaan karena baik buruknya struktur modal akan mempunyai efek langsung terhadap posisi finansial perusahaan, terutama dengan adanya utang yang sangat besar akan memberikan beban kepada perusahaan. Sehingga biasanya perusahaan akan lebih memilih berjaga-jaga dengan menahan laba yang diperoleh demi menambah dana yang diperuntukan membayar utangnya dibandingkan membagikan laba dalam bentuk dividen.

Bagi investor, Net Profit Margin biasanya digunakan untuk mengukur keefisienan pengelolahan manajemen. Dengan ini investor dapat melihat berapa persentase pendapatan yang digunakan untuk biaya operasional maupun biaya non-operasional serta berapa persentase tersisa yang dapat dibayar sebagai dividen kepada para pemegang saham ataupun berinvestasi kembali ke perusahaannya. Net Profit Margin yang tinggi menunjukan perusahaan menetapkan harga produknya dengan benar dan berhasil mengendalikan biaya dengan baik. Ukuran Perusahaan biasanya menunjukan tingkat pencapaian suatu perusahaan. Perusahaan besar biasanya lebih dipercaya untuk memiliki akses dari berbagai sumber pendanaan untuk membiayai perusahaannya sehingga laba yang diperoleh dapat dibayarkan sebagai dividen kepada para pemegang saham. Pada sisi lain, perusahaan dengan skala kecil lebih memilih menahan laba atau pendapatannya dibandingkan membayar dividennya. Hal ini dikarenakan perusahaan akan mengalokasikan laba ke laba ditahan untuk membiayai perusahaan dimasa yang akan datang.

Dalam penelitian ini akan dibahas beberapa faktor yang mempengaruhi Kebijakan Dividen diantaranya adalah Struktur Modal, Net Profit Margin (NPM) dan Ukuran Perusahaan. Perkembangan beberapa perusahaan sub sektor Consumer Goods dapat dilihat dari Tabel I.1 berikut ini:

\begin{tabular}{|c|c|c|c|c|c|}
\hline \multicolumn{6}{|c|}{ 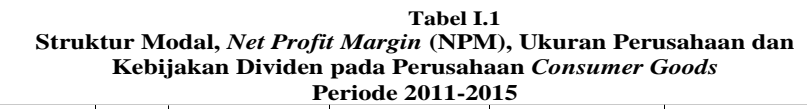 } \\
\hline $\begin{array}{c}\text { Nama } \\
\text { Perusahaan }\end{array}$ & Tahun & Total Hutang & Laba Setelah Pajak & Total Aset & Dividen Kas \\
\hline \multirow{5}{*}{$\begin{array}{l}\text { PT. Delta } \\
\text { Djakarta, } \\
\text { Tbk }\end{array}$} & 2011 & $123,231,249,000$ & $151,715,042,000$ & $696,166,676,000$ & $187,830,906,000$ \\
\hline & 2012 & $147,095,322,000$ & $213,421,077,000$ & $745,306,835,000$ & $191,869,037,000$ \\
\hline & 2013 & $190,482,809,000$ & $270,498,062,000$ & $867,040,802,000$ & $144,831,127,000$ \\
\hline & 2014 & $227,473,881,000$ & $288,073,432,000$ & $991,947,134,000$ & $156,878,293,000$ \\
\hline & 2015 & $188,700,435,000$ & $192,045,199,000$ & $1,038,321,916,000$ & $96,034,454,000$ \\
\hline \multirow{5}{*}{$\begin{array}{l}\text { PT. Darya } \\
\text { Varia } \\
\text { Laboratoria } \\
\text {, Tbk }\end{array}$} & 2011 & $200,373,603,000$ & $120,915,340,000$ & $928,290,993,000$ & $35,280,000,000$ \\
\hline & 2012 & $233,144,997,000$ & $148,909,089,000$ & $1,074,691,476,000$ & $52,640,000,000$ \\
\hline & 2013 & $275,351,336,000$ & $125,796,473,000$ & $1,190,054,288,000$ & $24,640,000,000$ \\
\hline & 2014 & $273,816,042,000$ & $80,929,476,000$ & $1,236,247,525,000$ & $78,114,771,000$ \\
\hline & 2015 & $402,760,903,000$ & $107,894,430,000$ & $1,376,278,237,000$ & $39,057,386,000$ \\
\hline \multirow{5}{*}{$\begin{array}{l}\text { PT. Gudang } \\
\text { Garam, Tbk }\end{array}$} & 2011 & $14,537,777,000,000$ & $4,958,102,000,000$ & $39,088,705,000,000$ & $1,981,627,000,000$ \\
\hline & 2012 & $14,903,612,000,000$ & $4,068,711,000,000$ & $41,509,325,000,000$ & $1,571,975,000,000$ \\
\hline & 2013 & $21,353,980,000,000$ & $4,383,932,000,000$ & $50,770,251,000,000$ & $1,582,869,000,000$ \\
\hline & 2014 & $24,991,880,000,000$ & $5,395,293,000,000$ & $58,220,600,000,000$ & $1,567,967,000,000$ \\
\hline & 2015 & $25,497,504,000,000$ & $6,452,834,000,000$ & $63,505,413,000,000$ & $5,024,366,000,000$ \\
\hline
\end{tabular}


Berdasarkan pada Tabel I.1, dapat dilihat bahwa PT. Delta Djakarta, Tbk (DLTA), memiliki total hutang tahun 2011 sebesar Rp. 123.231.249.000 dan pada tahun 2012 sebesar Rp. 147.095.322.000 mengalami kenaikan sebesar 19,37\% sedangkan dividen kas pada tahun 2011 sebesar Rp 187.830.906.000 dan tahun 2012 sebesar Rp 191.869.037.000 mengalami kenaikan sebesar 2,15\%. Fenomena ini tidak mendukung hasil penelitian Nasution (2018) yang menyatakan bahwa semakin tinggi tingkat hutang perusahaan maka akan mengurangi jumlah dividen yang akan dibagikan kepada pemegang saham, hal ini dikarenakan hutang merupakan kewajiban perusahaan yang harus dibayar tepat waktu dan lebih diutamakan dibandingkan hal yang lain, semakin besar hutang maka akan mengurangi jumlah laba yang tersedia bagi para pemegang saham. Perusahaan dengan tingkat hutang lebih rendah lebih mampu membayar dividen dibandingkan perusahaan dengan tingkat hutang yang tinggi.

PT. Darya Varia Laboratoria, Tbk (DVLA) memiliki total laba setelah pajak pada tahun 2013 sebesar Rp. 125.796.473.000 dan pada tahun 2014 sebesar Rp. 80.929.476.000 mengalami penurunan sebesar 35,37\% sedangkan dividen kas pada tahun 2013 sebesar Rp 24.640.000.000 dan tahun 2014 sebesar Rp 78.114.771.000 mengalami kenaikan sebesar 217,02\%. Fenomena ini tidak mendukung penelitian Nasution (2018) dimana Semakin tinggi profitabilitas perusahaan maka semakin tinggi kebijakan dividen perusahaan, begitu sebaliknya. Hasil ini sejalan dengan signaling theory yang menyatakan pembayaran dividen merupakan sumber informasi bahwa perusahaan berada dalam kondisi yang sangat baik bahkan investor memandang pemberian dividen dikarenakan kinerja perusahaan yang baik

PT. Gudang Garam, Tbk (GGRM) memiliki total aset pada tahun 2011 sebesar Rp. 39.088.705.000.000 dan pada tahun 2012 sebesar Rp. 41.509.325.000.000 mengalami kenaikan sebesar 6,19\% sedangkan dividen kas pada tahun 2011 sebesar Rp. 1.981.627.000.000 dan tahun 2012 sebesar Rp. 1.571.975.000.000 mengalami penurunan sebesar 20,67\%. Fenomena ini juga tidak sesuai dengan hasil penelitan Setiawan dan Phua (2013) menemukan adanya hubungan positif antara pertumbuhan perusahaan yang dilihat dari kenaikan total aset dan kebijakan dividen, yang berarti bahwa perusahaan yang memiliki tingkat pertumbuhan lebih tinggi memberikan dividen lebih tinggi kepada investor.

Berdasarkan fenomena dan teori telah dikemukakan diatas, maka rumusan masalah penelitian ini adalah Bagaimana pengaruh Struktur Modal, Net Profit Margin dan Ukuran Perusahaan terhadap Kebijakan Dividen pada perusahaan sub sektor Consumer Goodsyang terdaftar di Bursa Efek Indonesia periode 2011-2015.

\section{KAJIAN LITERATUR}

Kebijakan dividen merupakan keputusan untuk membagi laba yang diperoleh perusahaan kepada pemegang saham sebagai dividen atau akan menahan dalam bentuk laba ditahan untuk digunakan sebagai 
pembiayaan investasi pada masa yang akan datang (Mulyawan, 2015:253). Apabila perusahaan memilih untuk membagikan laba sebagai dividen maka akan mengurangi laba ditahan dan selanjutnya akan mengurangi total sumber dana intern atau intern financing. Sebaliknya jika perusahaan lebih memilih untuk menahan laba yang diperoleh, maka kemampuan pembentukan dana intern akan semakin besar (Sartono, 2010:281).Menurut Riyanto (2009:267) faktor-faktor yang mempengaruhi kebijakan dividen suatu perusahaan dapatlah disebutkan antara lain sebagai berikut:

1. Posisi Likuiditas Perusahaan

2. Kebutuhan Dana untuk Membayar Utang

3. Tingkat Pertumbuhan Perusahaan

4. Pengawasanterhadap Perusahaan

Struktur modal merupakan gambaran dari bentuk proporsi finansial perusahaan yaitu antara modal yang dimiliki yang bersumber dari utang jangka panjang (long-term liabilities) dan modal sendiri (shareholders' equity) yang menjadi sumber pembiayaan suatu perusahaan. Kebutuhan dana untuk memperkuat struktur modal suatu perusahaan dapat bersumber dari internal dan eksternal, dengan ketentuan sumber dana yang dibutuhkan tersebut bersumber dari tempat-tempat yang dianggap aman (safety position) dan jika dipergunakan memiliki nilai dorong dalam memperkuat struktur modal keuangan perusahaan. (Fahmi, 2016:184-185). Menurut Riyanto (2009:267) apabila perusahaan menetapkan bahwa pelunasan utangnya akan diambilkan dari laba ditahan, berarti perusahaan harus menahan sebagian besar dari pendapatannya untuk keperluan tersebut, yang ini berarti bahwa hanya sebagian kecil saja dari pendapatan atau earning yang dapat dibayarkan sebagai dividen. Dengan kata lain perusahaan harus menetapkan dividend payout ratio yang rendah.

Net profit margin merupakan rasio yang mengukur kemampuan perusahaan untuk menghasilkan laba bersih dari penjualan yang dilakukan perusahaan (Sudana, 2011:23). Semakin tinggi margin laba bersih semakin tinggi pula laba bersih yang dihasilkan dari penjualan bersih. Hal ini dapat disebabkan karena tingginya laba sebelum pajak penghasilan. Sebaliknya, semakin rendah margin laba bersih berarti semakin rendah pula laba bersih yang dihasilkan dari penjualan bersih. Hal ini dapat disebabkan oleh rendahnya laba sebelum pajak penghasilan. Perusahaan yang memiliki stabilitas dalam memperoleh keuntungan dapat memberikan sinyal kepada publik mengenai kemampuan perusahaan dalam membayar dividen (Hery, 2013:39).

Ukuran Perusahaan merupakan skala yang menyatakan besar atau kecilnya suatu perusahaan yang dilihat dari jumlah modal aset secara keseluruhan yang dimiliki suatu perusahaan. Menurut Jusuf (2014:7) aktiva (asset) dapat didefinisikan sebagai sumber daya yang dikuasai oleh perusahaan sebagai akibat dari peristiwa masa lalu dan dari mana manfaat ekonomi di masa depan diharapkan akan diperoleh perusahaan. Semakin besar ukuran suatu perusahaan, maka kecenderungan menggunakan modal asing 
juga semakin besar. Hal ini disebabkan karena perusahaan besar membutuhkan dana yang besar pula untuk menunjang operasionalnya, dan salah satu alternatif pemenuhannya adalah dengan modal asing apabila modal sendiri tidak mencukupi (Halim, 2015:125). Menurut Gumanti (2013:28) ada kecenderungan yang nyata dan berpola antara ukuran perusahaan dan besar kecilnya rasio pembayaran dividen. Perusahaan secara ekonomi dikelompokkan sebagai perusahaan besar, biasanya diukur dengan tingkat kapitalisasi pasar sahamnya, secara rata-rata memiliki rasio pembayaran dividen lebih tinggi daripada perusahaan kecil.

\section{Tabel II.1}

\section{Penelitian Terdahulu}

\begin{tabular}{|c|c|c|c|c|}
\hline $\mathrm{N}_{0}$ & Nama dan Tahun Penelitian & Judul & Variabel & Hasil Penelitian \\
\hline 1 & $\begin{array}{l}\text { Agnes Sulistyowati, Suhadak } \\
\text { dan Achmad Husaini (2014) }\end{array}$ & $\begin{array}{l}\text { Pegaruh Struktur } \\
\text { Modal Terhadap } \\
\text { Kebijakan Dividen }\end{array}$ & $\begin{array}{l}\text { Independen: } \\
\text { Struktur Modal } \\
\\
\text { Dependen: } \\
\text { Kebijakan Dividen }\end{array}$ & $\begin{array}{l}\text { DER berpengaruh signifikan dengan } \\
\text { arah positif terhadap DPR. }\end{array}$ \\
\hline 2 & $\begin{array}{l}\text { Kadek Dwi Mahendra Yasa dan } \\
\text { Ni Gusti Putu Wirawati (2016) }\end{array}$ & $\begin{array}{l}\text { Pengaruh Net Profit } \\
\text { Margin, Current } \\
\text { Ratio, Dan } \\
\text { Debt To Equity Ratio } \\
\text { Pada Dividend } \\
\text { Payout Ratio }\end{array}$ & $\begin{array}{l}\text { Independen: Net } \\
\text { Profit Margin, } \\
\text { Current Ratio dan } \\
\text { Debt to Equity } \\
\\
\text { Dependen: } \\
\text { Dividen Payout } \\
\text { Ratio }\end{array}$ & $\begin{array}{l}\text { Net Profit Margin berpengaruh } \\
\text { positif } \\
\text { dan signifikan secara statistik } \\
\text { terhadap Dividend Payout Ratio }\end{array}$ \\
\hline 3 & $\begin{array}{l}\text { Nindi Septia One Dhira, Novi } \\
\text { Wulandari dan Nining Ika } \\
\text { Wahyuni (2013) }\end{array}$ & $\begin{array}{l}\text { Pengaruh Laba } \\
\text { Bersih, Arus Kas } \\
\text { Operasi dan Ukuran } \\
\text { Perusahaan Terhadap } \\
\text { Kebijakan Dividen }\end{array}$ & $\begin{array}{l}\text { Independen: Laba } \\
\text { Bersih, Arus Kas } \\
\text { dan Ukuran } \\
\text { Perusahaan } \\
\\
\text { Dependen: } \\
\text { Kebijakan Dividen }\end{array}$ & $\begin{array}{l}\text { Secara parsial dan simultan semua } \\
\text { variabel bebas yaitu laba bersih, } \\
\text { arus kas operasi dan ukuran } \\
\text { perusahaan berpengaruh secara } \\
\text { signifkan terhadap variabel } \\
\text { terikatnya kebijakan dividen. }\end{array}$ \\
\hline
\end{tabular}

Berdasarkan uraian teori-teori diatas maka peneliti membuat kerangka konseptual yang dapat dilihat pada Gambar II.1:

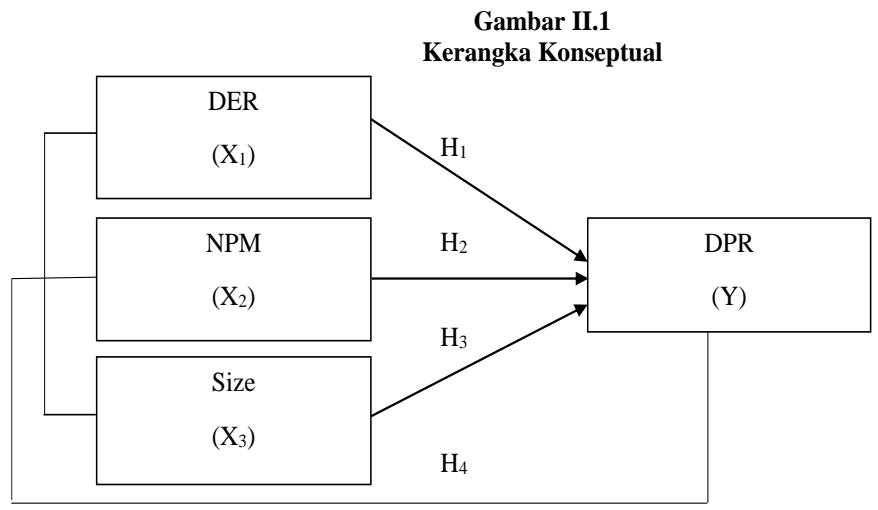


Dari kerangka konsep dan landasan teori yang telah dijelaskan di atas, maka hipotesis yang akan dikemukakan dalam penelitian ini adalah sebagai berikut:

$\mathrm{H}_{1} \quad$ Struktur Modal berpengaruh signifikan secara parsial terhadap Kebijakan Dividen pada perusahaan sub sektor Consumer Goodsyang terdaftar di Bursa Efek Indonesia periode 20112015.

$\mathrm{H}_{2} \quad$ Net Profit Margin (NPM) berpengaruh signifikan secara parsial terhadap Kebijakan Dividen pada perusahaan sub sektor Consumer Goodsyang terdaftar di Bursa Efek Indonesia periode 20112015.

$\mathrm{H}_{3} \quad$ Ukuran Perusahaan berpengaruh signifikan secara parsial terhadap Kebijakan Dividen pada perusahaan sub sektor Consumer Goodsyang terdaftar di Bursa Efek Indonesia periode 20112015.

$\mathrm{H}_{4} \quad$ Struktur Modal, Net Profit Margin (NPM) dan Ukuran Perusahaan berpengaruh signifikan secara simultan terhadap Kebijakan Dividen pada perusahaan sub sektor Consumer Goodsyang terdaftar di Bursa Efek Indonesia periode 2011-2015.

\section{METODE}

Pendekatan penelitian yang digunakan adalah penelitian kuantitatif, jenis penelitiannya adalah penelitian deskriptif dan sifat penelitiannya adalah penelitian eksplanatori. Jenis data yang digunakan dalam penelitian ini adalah data sekunder dan metode pengumpulan data dilakukan dengan studi dokumentasi.Populasi penelitianiniadalah perusahaan di sektorConsumer Goodsyang terdaftar di Bursa EfekIndonesiasejaktahun 2011 sampaidengantahun2015, yang berjumlah 40 perusahaan. Teknik pengambilan sampel dalam penelitian ini menggunakan purposive sampling.

\section{Tabel III.1}

\section{Kriteria Pemilihan Sampel}

\begin{tabular}{|l|l|c|}
\hline No & \multicolumn{1}{|c|}{ Kriteria } & Jumlah \\
\hline 1. & $\begin{array}{l}\text { Perusahaan yang terdaftar secara berturut-turut dalam sub-sektor consumer } \\
\text { goods di BEI periode 2011-2015 }\end{array}$ & 37 \\
\hline 2. & $\begin{array}{l}\text { Perusahaan sub-sektor consumer goods yang tidak mempublikasikan secara } \\
\text { berturut-turut laporan keuangan tahunan yang telah diaudit periode 2011- } \\
2015\end{array}$ & $(6)$ \\
\hline 3. & $\begin{array}{l}\text { Perusahaan sub sektor consumer goods yang tidak mendapatkan profit } \\
\text { secara berturut-urut selama periode 2011-2015 }\end{array}$ & $(1)$ \\
\hline 4. & $\begin{array}{l}\text { Perusahaan sub-sektor consumer goods yang tidak membagikan dividen } \\
\text { berturut-turut selama periode 2011-2015 }\end{array}$ & $(13)$ \\
\hline \multicolumn{1}{|c|}{ Jumlah perusahaan yang terpilih menjadi sampel penelitian } & 17 \\
\hline
\end{tabular}


Berdasarkan kriteria pemilihan sampel diatas, maka sampel penelitian menjadi 17 sampel, sehingga observasi pengamatan menjadi 17 X $5=85$ observasi pengamatan.

\section{Tabel III.2}

\section{Definisi Operasional Variabel Penelitian}

\begin{tabular}{|c|c|c|c|}
\hline Variabel & Definisi & Indikator & \begin{tabular}{|l|} 
Skala \\
Ukur
\end{tabular} \\
\hline $\begin{array}{l}\text { Struktur } \\
\text { Modal }\left(X_{\mathrm{I}}\right)\end{array}$ & $\begin{array}{l}\text { Struktur modal adalah merupakan } \\
\text { perimbangan jumlah utang jangka } \\
\text { pendek yang bersifat permanen, } \\
\text { utang jangka panjang, saham } \\
\text { preferen dan saham biasa. } \\
\text { Sumber: Sartono (2010:225) } \\
\end{array}$ & $\begin{array}{l}\text { Debt to Equity Ratio } \\
=\frac{\text { Total Utang (Debt) }}{\text { Ekuitas(Equity) }} \\
\text { Sumber:Kasmir (2012:158) }\end{array}$ & Rasio \\
\hline $\begin{array}{l}\text { Net Profit } \\
\text { Margin }\left(X_{2}\right)\end{array}$ & $\begin{array}{l}\text { Net Profit Margin merupakan } \\
\text { rasio yang mengukur kemampuan } \\
\text { perusahaan untuk menghasilkan } \\
\text { laba bersih dari penjualan yang } \\
\text { dilakukan perusahaan. } \\
\text { Sumber:Sudana (2011:23) } \\
\end{array}$ & $\begin{array}{l}\text { Net Profit Margin } \\
=\frac{\text { Laba Bersih setelah Bunga dan Pajak }}{\text { Penjualan }} \\
\text { Sumber: Kasmir (2012:200) }\end{array}$ & Rasio \\
\hline $\begin{array}{l}\text { Ukuran } \\
\text { Perusahaan } \\
\left(X_{3}\right)\end{array}$ & $\begin{array}{l}\text { aktiva merupakan harta atau } \\
\text { kekayaan yang dimiliki oleh } \\
\text { perusahaan, baik pada saat } \\
\text { tertentu maupun periode tertentu. } \\
\text { Sumber:Kasmir (2012:39) } \\
\end{array}$ & $\begin{array}{l}\text { Ukuran Perusahaan = In total asset } \\
\text { Sumber:Rodoni dan Ali (2014:193) }\end{array}$ & Nominal \\
\hline $\begin{array}{l}\text { Kebijakan } \\
\text { Dividen (Y) }\end{array}$ & $\begin{array}{l}\text { kebijakan dividen merupakan } \\
\text { dividen tunai tahunan yang dibagi } \\
\text { dengan laba tahunan; atau dividen } \\
\text { perlembar saham dibagi dengan } \\
\text { laba per lembar saham. } \\
\text { Sumber:Van Horne (2010:270) } \\
\end{array}$ & $\begin{array}{l}\text { DPR }=\frac{\text { dividen }}{\text { laba setelah pajak }} \\
\text { Sumber: Sudana (2011:24) }\end{array}$ & Rasio \\
\hline
\end{tabular}

Hipotesis diuji dengan analisis regresi linier bergandamenggunakan program SPSS, untuk menganalisis pengaruh variabel independen terhadap variabel dependen. Model regresi yang digunakan yaitu :

$$
Y=a+b_{1} X_{1+} b_{2} X_{2}+b_{3} X_{3}+e
$$

Keterangan:

Y = Kebijakan Dividen

a $\quad=$ Konstanta

$\mathrm{b}_{1} \quad=$ Koefisien Regresi Variabel $\mathrm{X}_{1}$ (Struktur Modal)

$\mathrm{b}_{2} \quad=$ Koefisien Regresi Variabel $\mathrm{X}_{2}$ (Net Profit Margin)

$\mathrm{b}_{3} \quad=$ Koefisien Regresi Variabel $\mathrm{X}_{3}$ (Ukuran Perusahaan)

$\mathrm{X}_{1} \quad=$ Variabel Struktur Modal

$\mathrm{X}_{2} \quad=$ Variabel Net Profit Margin

$\mathrm{X}_{3} \quad=$ Variabel Ukuran Perusahaan

$\mathrm{e} \quad=$ Persentase Kesalahan 


\section{HASIL DAN PEMBAHASAN}

\section{Uji Asumsi Klasik}

Untuk menghasilkan suatu model regresi yang baik, analisi regresi memerlukan pengujian asumsi klasik terlebih dahulu sebelum melakukan pengujian hipotesis.

\section{Uji Normalitas}

\section{Analisis Grafik}

Metode yang lebih handal adalah dengan melihat normal probability plot yang membandingkan kumulatif dari distribusi normal. Hasil uji normalitas dari grafik histogram dapat dilihat pada Gambar IV.1 sebagai berikut:

\section{Gambar IV.1}

\section{Hasil Analisis Grafik Histrogram}

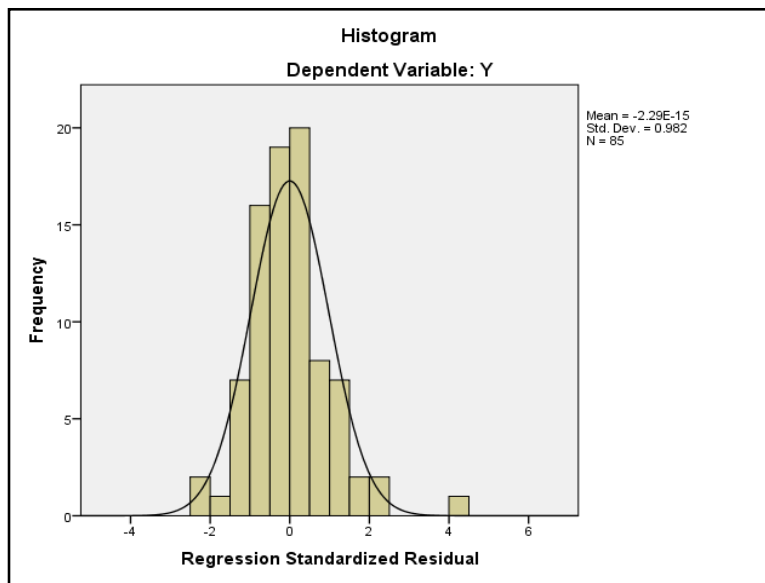

Dari hasil histogram pada Gambar IV.1 dapat disimpulkan bahwa data residual berdistribusi normal dengan histogram membentuk lonceng terbalik.

Demikian pula dengan hasil normal probability plot berikut ini: 


\section{Gambar IV.2}

Hasil Analisis Normal Probability Plot

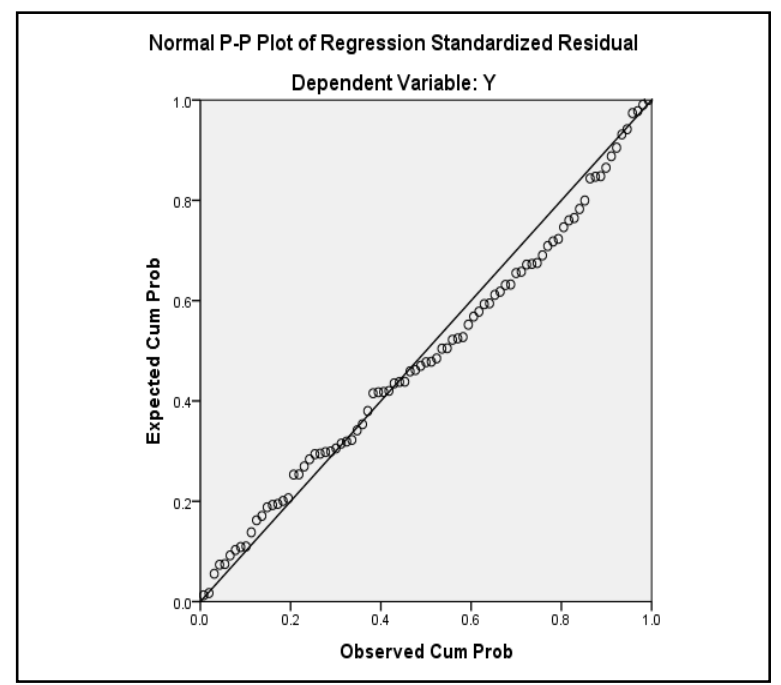

Sumber: Pengolah Data SPSS

Dari hasil normal probability plot pada Gambar IV.2 dapat disimpulkan bahwa data residual berdistribusi normal dengan titik-titik menyebar disekitar garis diagonal dan mengikuti arah garis diagonal baik diatas maupun dibawah garis diagonal.

Analisis Statistik

Analisis statistik menggunakan uji statistik non parametrik Kolmogrov Smirnov untuk menguji normalitas residual. Hasil dari uji normalitas dengan menggunakan Kolmogrov Smirnov Test adalah sebagai berikut:

Tabel IV.1

\section{Hasil Uji Statistik Kolmogrov Smirnov}

One-Sample Kolmogorov-Smirnov Test

\begin{tabular}{|ll|r|}
\hline & & Unstandardized Residual \\
\hline N & Mean & 85 \\
& Std. Deviation & $0 \mathrm{E}-7$ \\
& Absolute & .27060667 \\
Most Extreme Differences & Positive & .075 \\
& Negative & .075 \\
Kolmogorov-Smirnov Z & & -.049 \\
Asymp. Sig. (2-tailed) & & .691 \\
\hline
\end{tabular}

a. Test distribution is Normal.

b. Calculated from data.

\section{Sumber: Pengolah Data SPSS}


Dari hasil uji statistik Kolmogrov Smirnov pada Tabel IV.1 menunjukkan bahwa variabel Struktur Modal $\left(\mathrm{X}_{1}\right)$, Net Profit Margin $\left(\mathrm{X}_{2}\right)$, Ukuran Perusahaan $\left(\mathrm{X}_{3}\right)$ dan Kebijakan Dividen (Y) memiliki nilai signifikan $0,726>0,05$ sudah memenuhi syarat data residual berdistribusi normal.

\section{Uji Multikolinieritas}

Untuk mendeteksi ada atau tidak terjadinya multikolinieritas didalam model regresi dapat dilihat dari nilai tolerance dan Variance Inflation Factor (VIF). Hasil penelitian dari uji multikolinieritas adalah sebagai berikut:

\section{Tabel IV.2}

\section{Hasil Uji Multikolinieritas}

\begin{tabular}{|c|c|c|c|c|c|c|c|c|}
\hline \multicolumn{9}{|c|}{ Coefficients $^{\mathrm{a}}$} \\
\hline & \multirow[b]{2}{*}{ Model } & \multicolumn{2}{|c|}{ Unstandardized Coefficients } & \multirow{2}{*}{$\begin{array}{c}\begin{array}{c}\text { Standardized } \\
\text { Coefficients }\end{array} \\
\text { Beta }\end{array}$} & \multirow[b]{2}{*}{ t } & \multirow[b]{2}{*}{ Sig. } & \multicolumn{2}{|c|}{ Collinearity Statistics } \\
\hline & & $\mathrm{B}$ & Std. Error & & & & Tolerance & $\mathrm{VIF}$ \\
\hline 1 & (Constant) & -1.222 & .570 & & -2.143 & .035 & & \\
\hline & $\mathrm{X} 1$ & .073 & .049 & .129 & 1.496 & .139 & .976 & 1.025 \\
\hline & $\mathrm{X} 2$ & 2.651 & .361 & .672 & 7.340 & .000 & .871 & 1.148 \\
\hline & $\mathrm{X} 3$ & .048 & .019 & .230 & 2.490 & .015 & .854 & 1.172 \\
\hline
\end{tabular}

Dari hasil uji multikolinieritas pada Tabel IV.2 menunjukkan bahwa besarnya nilai tolerance yang diperoleh untuk variabel Struktur Modal $\left(\mathrm{X}_{1}\right)$ sebesar $(0,976)$, Net Profit Margin $\left(\mathrm{X}_{2}\right)$ sebesar $(0,871)$ dan Ukuran Perusahaan $\left(\mathrm{X}_{3}\right)$ sebesar $(0,854)$ masing-masing lebih besar dari 0,10 maka dapat disimpulkan bahwa tidak terjadi multikolinieritasantar variabel independen dalam model regresi tersebut. Nilai VIF yang diperoleh untuk variabel Struktur Modal $\left(\mathrm{X}_{1}\right)$ sebesar $(1,025)$, Net Profit Margin $\left(\mathrm{X}_{2}\right)$ sebesar $(1,148)$ dan Ukuran Perusahaan $\left(\mathrm{X}_{3}\right)$ sebesar $(1,172)$ masing-masing lebih kecil dari 10 maka dapat disimpulkan bahwa tidak terjadi multikolinieritas antar variabel independen dalam model regresi tersebut.

\section{Uji Autokolerasi}

Untuk mendeteksi ada tidak terjadinya autokolerasi didalam model regresi dapat menggunakan beberapa cara diantaranya dengan menggunakan uji Run Test. Hasil penelitian dari uji autokolerasi dengan meggunakan uji Run Test adalah sebagai berikut: 


\section{Tabel IV.3}

\section{Hasil Uji Autokolerasi}

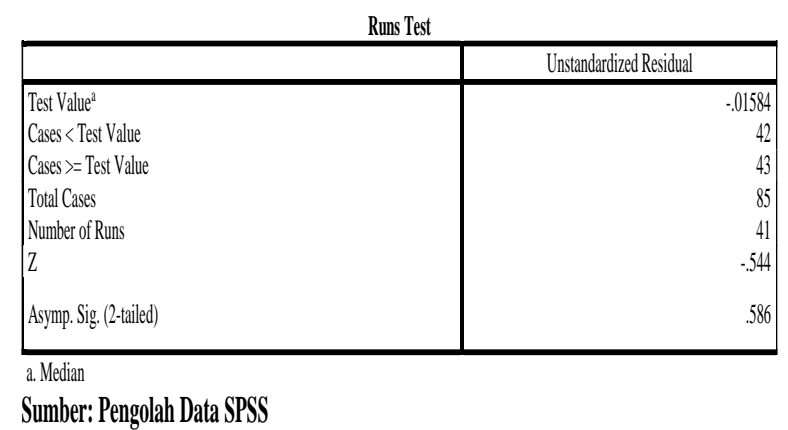

Dari hasil uji autokolerasi menggunakan uji Run Test pada Tabel IV.3 menunjukkan bahwa nilai signifikan yang diperoleh adalah sebesar 0,586>0,05 sehingga dapat disimpulkan bahwa tidak ada autokolerasi dalam model regresi tersebut.

\section{Uji Heterokedastisitas}

Untuk mendeteksi ada tidak terjadinya heterokedastisitas didalam model regresi menggunakan Uji Grafik.Uji ini mendeteksi tidak terjadi heterokedastisitas didalam model regresi dengan melihat grafik scatterplot tidak ada pola yang jelas, seperti titik-titik menyebar di atas dan di bawah angka 0 pada sumbu Y. Hasil penelitian dari uji heterokedastisitas menggunakan uji grafik scatterplot adalah sebagai berikut:

\section{Gambar IV.3}

\section{Hasil Uji Scatterplot}

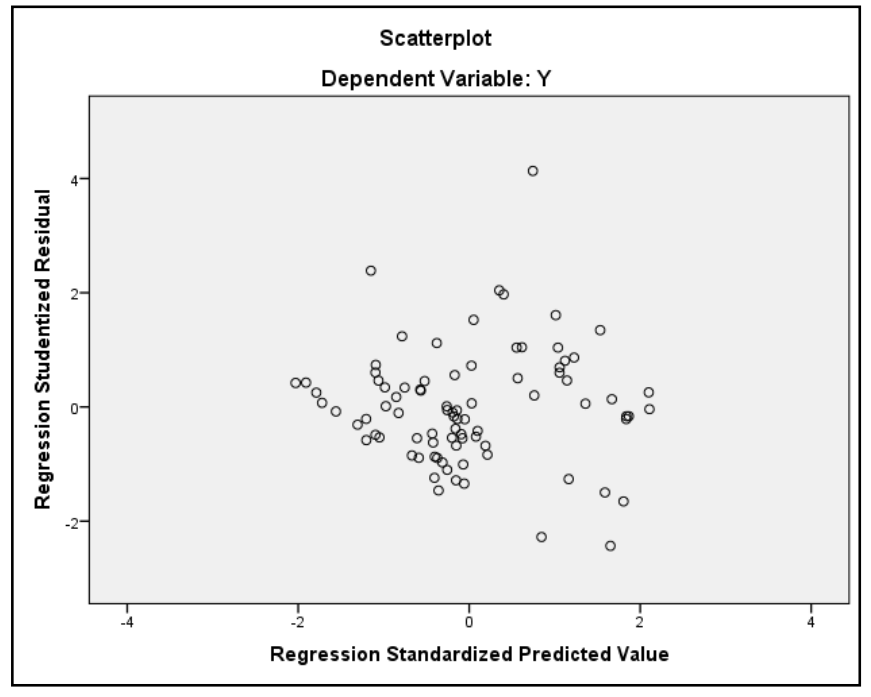

Sumber: Pengolah Data SPSS 
Dari hasil grafik scatterplotpada Gambar IV.3 dapat disimpulkan bahwa tidak terjadi heterokedastisitas didalam model regresi dengan titik-titik menyebar di atas dan di bawah angka 0 pada sumbu Y.

\section{Analisis Data Penelitian}

\section{Analisis Regresi Linear Berganda}

Hasil analisis regresi linear berganda dalam penelitian ini adalah sebagai berikut:

\section{Tabel IV.4}

\section{Hasil Uji Analisis Regresi Linear Berganda}

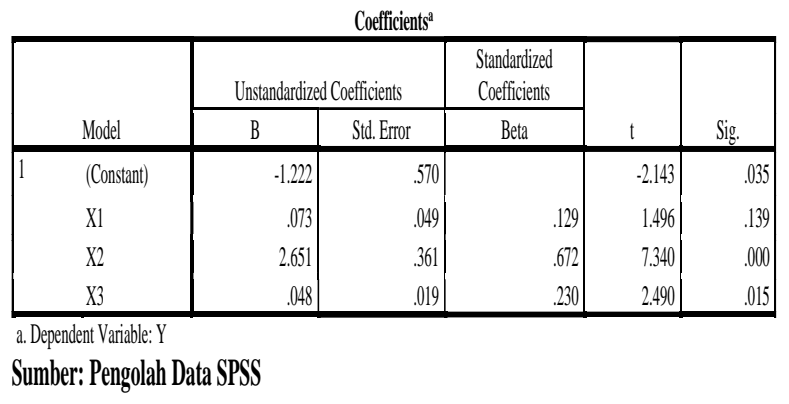

Dari hasil uji analisis regresi linear berganda pada Tabel IV.4 menunjukkan persamaan regresi linear berganda dalam penelitian ini adalah sebagai berikut:

$$
\mathrm{Y}=-1,222+0,073 \mathrm{X}_{1}+2,651 \mathrm{X}_{2}+0,048 \mathrm{X}_{3}
$$

Hasil interpretasi dari regresi tersebut adalah sebagai berikut:

1. Nilai a sebesar -1,222 artinya jika variabel Struktu Modal $\left(\mathrm{X}_{1}\right)$, Net Profit Margin $\left(\mathrm{X}_{2}\right)$ dan Ukuran Perusahaan $\left(\mathrm{X}_{3}\right)$ dianggap konstan, maka Kebijakan Dividen ( $\mathrm{Y}$ ) pada perusahaan sub sektor consumer goods yang terdaftar di Bursa Efek Indonesia periode 2011-2015 adalah sebesar $-1,222$.

2. Nilai koefisien Struktu Modal $\left(\mathrm{X}_{1}\right)$ adalah sebesar 0,073. Ini menunjukkan bahwa setiap terjadi perubahan Struktu Modal $\left(\mathrm{X}_{1}\right)$ satu kali maka Kebijakan Dividen (Y) akan mengalami kenaikan sebesar 0,073 .

3. Nilai koefisien Net Profit Margin $\left(\mathrm{X}_{2}\right)$ adalah sebesar 2,651. Ini menunjukkan bahwa setiap terjadi perubahan Net Profit Margin $\left(\mathrm{X}_{2}\right)$ satu kali maka Kebijakan Dividen (Y) akan mengalami kenaikan sebesar 2,651.

4. Nilai koefisien Ukuran Perusahaan $\left(\mathrm{X}_{3}\right)$ adalah sebesar 0,048. Ini menunjukkan bahwa setiap terjadi perubahan Ukuran Perusahaan $\left(\mathrm{X}_{3}\right)$ satu kali maka Kebijakan Dividen (Y) akan mengalami kenaikan sebesar 0,048. 


\section{Koefisien Determinasi $\left(\mathbf{R}^{2}\right)$}

Uji koefisien determinasi $\left(\mathrm{R}^{2}\right)$ digunakan untuk mengukur seberapa besar kemampuan pengaruh variabel bebas dapat menjelaskan variabel terikat. Hasil perhitungan koefisien determinasi dapat dilihat pada Tabel IV.4 berikut ini:

\section{Tabel IV.5}

\section{Hasil Uji Koefisien Determinasi $\left(\mathbf{R}^{2}\right)$}

\begin{tabular}{|c|c|c|c|c|}
\hline \multicolumn{5}{|c|}{ Model Summary ${ }^{b}$} \\
\hline Model & $\bar{R}$ & R Square & Adjusted R Square & Std. Error of the Estimate \\
\hline 1 & $.639^{a}$ & .409 & .387 & .275572 \\
\hline $\begin{array}{l}\text { a. Predi } \\
\text { b. Depe } \\
\text { sumb }\end{array}$ & $\mathrm{X} 3, \mathrm{X}, \mathrm{X} 2$ & & & \\
\hline
\end{tabular}

Pada Tabel IV.5 hasil analisis regresi dapat dilihat nilai Adjusted R Square sebesar 0,387 mengindikasikan bahwa variasi dari Struktur Modal $\left(\mathrm{X}_{1}\right)$, Net Profit Margin $\left(\mathrm{X}_{2}\right)$ dan Ukuran Perusahaan $\left(\mathrm{X}_{3}\right)$ mampu menjelaskan variasi variabel atau berpengaruh terhadap Kebijakan Dividen (Y) sebesar $38,7 \%$. Sedangkan sisanya sebesar $61,3 \%$ dipengaruhi oleh faktor-faktor lain diluar variabel yang diteliti dalam penelitian ini.

\section{Pengujian Hipotesis Secara Simultan (Uji-F)}

\section{Tabel IV.6}

\section{Hasil Uji Statistik Secara Simultan (Uji-F)}

\begin{tabular}{|c|c|c|c|c|c|c|}
\hline \multicolumn{7}{|c|}{$\mathrm{ANOVA} \mathrm{A}^{\mathrm{a}}$} \\
\hline Mode & & Sum of Squares & df & Mean Square & $\mathrm{F}$ & Sig. \\
\hline 1 & Regression & 4.250 & 3 & 1.417 & 18.654 & $.000^{b}$ \\
\hline & Residual & 6.151 & 81 & .076 & & \\
\hline & Total & 10.401 & 84 & & & \\
\hline
\end{tabular}

Dari Tabel IV.6 diatas, dapat dilihat hasil $\mathrm{F}_{\text {hitung }}$ adalah sebesar 18,654 dengan nilai signifikan 0,000 sedangkan $F_{\text {tabel }}$ adalah sebesar 2,72 maka kesimpulannya adalah $F_{\text {hitung }}>F_{\text {tabel }}=18,654>2,72$ dengan nilai signifikan $0,000<0,05$ maka $\mathrm{H}_{\mathrm{a}}$ diterima dan $\mathrm{H}_{0}$ ditolak yang berarti variabel Struktur Modal $\left(\mathrm{X}_{1}\right)$, Net Profit Margin $\left(\mathrm{X}_{2}\right)$ dan Ukuran Perusahaan $\left(\mathrm{X}_{3}\right)$ secara simultan berpengaruh dan signifikan terhadap Kebijakan Dividen (Y) pada perusahaan sub sektor Consumer Goods yang terdaftar di Bursa Efek Indonesia periode 2011-2015. 


\section{Pengujian Hipotesis Secara Parsial (Uji-t)}

Hasil dari Uji t adalah sebagai berikut:

\section{Tabel IV.7}

\section{Hasil Uji Statistik Secara Parsial (Uji-t)}

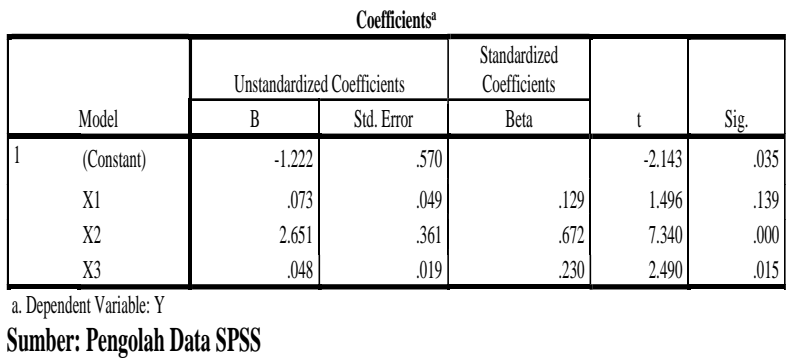

Hasil pengujian statistik secara parsial sebagai berikut:

1. Variabel Struktur Modal $\left(\mathrm{X}_{1}\right)$ mempunyai nilai signifikan $0,139>0,05$ dan hasil $\mathrm{t}_{\text {hitung }} \leq \mathrm{t}_{\text {tabel }}=$ 1,496 $\leq 1,98969$ maka $\mathrm{H}_{0}$ diterima dan $\mathrm{H}_{\mathrm{a}}$ ditolak yang berarti bahwa variabel Struktur Modal $\left(\mathrm{X}_{1}\right)$ secara parsial berpengaruh tidak signifikan terhadap Kebijakan Dividen (Y) pada perusahaan sub sektor Consumer Goods yang terdaftar di Bursa Efek Indonesia periode 2011-2015.

Hal ini dapat disimpulkan bahwa pada perusahaan sub sektor Consumer Goods yang terdaftar di Bursa Efek Indonesia periode 2011-2015 besar kecilnya nilai Struktur Modal tidak berpengaruh dalam menghasilkan Kebijakan Dividen. Hal ini dapat dilihat data dalam penelitian ini menunjukkan bahwa kenaikan struktur modal tidak diikut dengan penurunan kebijakan dividen, begitu juga sebaliknya.

2. Variabel Net Profit Margin $\left(\mathrm{X}_{2}\right)$ mempunyai nilai signifikan $0,000<0,05$ dan hasil $\mathrm{t}_{\text {hitung }}>\mathrm{t}_{\text {tabel }}=$ 7,340 > 1,98969 maka $\mathrm{H}_{\mathrm{a}}$ diterima dan $\mathrm{H}_{0}$ ditolak yang berarti bahwa variabel Net Profit Margin $\left(\mathrm{X}_{2}\right)$ secara parsial berpengaruh positif dan signifikan terhadap Kebijakan Dividen (Y) pada perusahaan sub sektor Consumer Goods yang terdaftar di Bursa Efek Indonesia periode 20112015.Hasil ini sejalan dengan signaling theory yang menyatakan pembayaran dividen merupakan sumber informasi bahwa perusahaan berada dalam kondisi yang sangat baik bahkan investor memandang pemberian dividen dikarenakan kinerja perusahaan yang baik.

3. Variabel Ukuran Perusahaan $\left(\mathrm{X}_{3}\right)$ mempunyai nilai signifikan $0,015<0,05$ dan hasil $t_{\text {hitung }}>t_{\text {tabel }}=$ 2,490 > 1,98969 maka $\mathrm{H}_{\mathrm{a}}$ diterima dan $\mathrm{H}_{0}$ ditolak yang berarti bahwa variabel Ukuran Perusahaan $\left(\mathrm{X}_{3}\right)$ secara parsial berpengaruh positif dan signifikan terhadap Kebijakan Dividen (Y) pada perusahaan sub sektor Consumer Goods yang terdaftar di Bursa Efek Indonesia periode 20112015. Hasil penelitian ini sejalan dengan Nasution (2018) yang menyatakan semakin besar ukuran perusahaan maka semakin besar kebijakan dividen perusahaan, begitu juga sebaliknya. 
Hal ini dikarenakan risiko perusahaan besar lebih terdiversifikasi dibandingkan perusahaan kecil, karena perusahaan besar dapat membagi risikonya dengan perusahaan-perusahaan dalam grup perusahaan tersebut sehingga perusahaan besar lebih tidak berisiko secara financial, sehingga perusahaan besar akan membagi dividen yang tinggi dibandingkan dengan perusahaan yang kecil

\section{KESIMPULAN}

\section{Kesimpulan}

Berdasarkan hasil analisis pengujian hipotesis yang dilakukan dengan menggunakan alat SPSS, diperoleh kesimpulan sebagai berikut:

1. Struktur Modal secara parsial berpengaruh tidak signifikan terhadap Kebijakan Dividen pada perusahaan Consumer Goods yang terdaftar di Bursa Efek Indonesia periode 2011-2015 dengan nilai $\mathrm{t}_{\text {hitung }} \leq \mathrm{t}_{\text {tabel }}$ atau $1,496 \leq 1,98969$ dan nilai signifikan sebesar $0,139>0,05$.

2. Net Profit Margin secara parsial berpengaruh positif dan signifikan terhadap Kebijakan Dividen pada perusahaan Consumer Goods yang terdaftar di Bursa Efek Indonesia periode 2011-2015 dengan hasil $\mathrm{t}_{\text {hitung }}>\mathrm{t}_{\text {tabel }}$ atau 7,340 $>1,98969$ dan nilai signifikan sebesar $0,000<0,05$.

3. Ukuran Perusahaan secara parsial berpengaruh positif dan signifikan terhadap Kebijakan Dividen pada perusahaan Consumer Goods yang terdaftar di Bursa Efek Indonesia periode 2011-2015 dengan hasil $\quad t_{\text {hitung }}>t_{\text {tabel }}$ atau 2,490 $\leq 1,98969$ dan nilai signifikan sebesar 0,015<0,05.

4. Struktur Modal, Net Profit Margin dan Ukuran Perusahaan secara simultan berpengaruh positif dan signifikan terhadap Kebijakan Dividen pada periode 2011-2015 dengan $F_{h i t u n g}>F_{\text {tabel }}$ atau 18,654 > 2,72 dengan nilai signifikan $0,000>0,05$.

5. Koefisien determinasi yang dihasilkan adalah nilai Adjusted $\mathrm{R}$ Square sebesar 0,387 mengindikasikan variabel dependen (Kebijakan Dividen) dapat dijelaskan oleh variabel independen (Struktur Modal, Net Profit Margin dan Ukuran Perusahaan) sebesar 38,7\%. Sedangkan sisanya sebesar 61,3\% dipengaruhi oleh faktor-faktor lain diluar variabel yang diteliti dalam penelitian ini.

\section{Saran}

Ada beberapa saran yang dapat dikemukakan peneliti berkaitan dengan hasil penelitian ini adalah sebagai berikut:

\section{Bagi Peneliti Selanjutnya}

Kepada peneliti selanjutnya yang ingin melanjutkan penelitian ini disarankan untuk menambahkan variabel lain seperti Pertumbuhan Perusahaan dan Likuiditas yang dapat mempengaruhi Kebijakan Dividen. Dengan meneliti perusahaan lainnya yang berada di Bursa Efek Indonesia.

\section{Bagi Perusahaan}


Berdasarkan penelitian ini, disarankan kepada perusahaan untuk memperhatikan kenaikan dividen yang diterapkan melalui laba bersih. Karena dalam penelitian untuk perusahaan yang bergerak dibidang Consumer Goods, Net Profit Margin memiliki kemampuan yang besar dalam mempengaruhi kenaikan Kebijakan Dividen.

3. Bagi Investor Pemberi Modal

Berdasarkan penelitian ini, disarankan kepada investor untuk memperhatikan kondisi keuangan perusahaan sebelum melakukan investasi dengan memperhatikan Struktur Modal, Net Profit Margin dan Ukuran Perusahaan dalam suatu perusahaan untuk mengetahui seberapa besar keuntungan yang akan diperoleh.

\section{REFERENSI}

Fahmi, Irfam. 2016. Pengantar Manajemen Keuangan, Teori dan Soal Jawab. Bandung: CV Alfabeta. Gumanti, Ari Tatang. 2013.Kebijakan Dividen Teori, Empiris, dan Implikasi. Jakarta: UPP STIM YKPN. Halim, Abdul. 2015.Manajemen Keuangan Bisnis, Konsep dan Aplikasinya. Jakarta: Mitra Wacana Media.

Hery. 2013.Teori Akuntansi. Edisi Pertama, Cetakan Kedua. Jakarta: Kencana.

Jusuf, Jopie. 2014. Analisi Kredit Untuk Credit (Account) Officer. Jakarta: PT Gramedia Pustaka Utama.

Kasmir. 2012. Analisis Laporan Keuangan. Jakarta: PT Rajagrafindo Persada.

Mulyawan, Setia. 2015. Manajemen Keuangan. Bandung: CV Pustaka Setia.

Nasution, Yusneni Afrita. 2018. The Analysis of Factors that Influence Dividend Policy in Manufacturing Companies Period 2013 - 2016 Registered in Indonesia Stock Exchange. International Journal of Public Budgeting, Accounting and Finance. V.1, N.4, p. 1-14, ISSN 2655-6693

Riyanto, Bambang. 2009.Dasar - Dasar Pembelajaan Perusahaan. Yogyakarta: BPFE-Yogyakarta. Rodoni, Ahmad dan Herni Ali. 2014. Manajemen Keuangan Modern. Jakarta: Mitra Wacana Media. Sartono, Agus. 2010.Manajemen Keuangan, Teori dan Aplikasi. Edisi 4. Yogyakarta: BPFE-Yogyakarta. Setiawan, Doddy., dan Phua, L. Kee. 2013. Corporate Governance dan Dividend Policy in Indonesia. Journal of Business Strategy Series. Vol.14, No.5/6. pp.135-143, Q Emerald Group Publishing Limited, ISSN 1751-5637.

Sudana, I Made. 2011. Manajemen Keuangan Perusahaan, Teori dan Praktik. Jakarta: Erlangga.

Van Horne, James C. dan John M. Wachowicz, JR. 2010. Prinsip - Prinsip Manajemen Keuangan. Edisi 12. Jakarta: Salemba Empat. 